\title{
Management of Urban Farming Activities In A Community Case Study 1000kebun In Bandung City
}

\author{
Ahkmad Zainal Mubarak ${ }^{3 *}$, Oekan S Abdoellah ${ }^{1,3,4}$, Susanti Withaningsih ${ }^{1,3}$, Kinanti Indah ${ }^{3}$ \\ ${ }^{1}$ Center for Environment and Sustainability Science, Universitas Padjadjaran, Indonesia \\ ${ }^{2}$ Sustainability Science Program, Postgraduate School, Universitas Padjadjaran, Indonesia \\ ${ }^{3}$ Environment Science Program, Postgraduate School, Universitas Padjadjaran, Indonesia \\ ${ }^{4}$ Department of Anthropology, Faculty of Social and Political Sciences, Universitas Padjadjaran
}

\begin{abstract}
Urban farming is a solution to the food crisis and deterioration of the environment urban conditions. In the city of Bandung, there are communities that carry out urban farming activities that are packaged attractively. The strategy carried out by the community in the practice of urban farming is a tool capable of driving from a downturn in urban areas. The study discusses urban farming as community management in 1000kebun to share knowledge and experience. Logical framework analysis carried out by the community of 1000kebun in the city of Bandung in forming a strategy developed so as to encourage the urban farming activities to remain sustainable. The strategies related to creativity in the agricultural sector and the involvement of young people in the agricultural sector. The 1000kebun community developed the creativity from the involvement of young people in carrying out agricultural activities which were able to encourage the wider community to care about the agricultural sector and consumption of foodstuffs that did not damage the environment and health. The motivation of 1000kebun to be active in the management of urban farming is to raise an active role for public concern in the agricultural sector, especially those in urban areas.
\end{abstract}

\section{Background}

Farmers' jobs in urban areas are considered as side jobs because they do not generate economic benefits. In addition, urban communities who do not have access to land have caused the decline in the agricultural sector in urban areas. By looking at the condition of the population in Bandung city 2019, a population rate of $0.43 \%$ and the productive age around (15 to 34 years) reaching 912 thousand people or $36 \%$ of the total population in Bandung City (BPS, 2018). This condition is increasingly supported by the consumption of urban people which spend $60 \%$ to $80 \%$ of their income to obtain food [16,22]

The condition of people in developing countries is still dependent on access to natural resources, especially land that is used as a source of income. The agricultural sector is less attractive to many young people (Proctor and Lucchrsi, 2012). Most of the youth suppose that the agricultural sector is tiring, tedious and need more energy to make a profit. In fact, KRKP (2015) reports that there are only $54 \%$ of young generation interested in crops and $36.7 \%$ of young generation interested in horticulture. It reveals that there are still youth who are interested in the agricultural sector. New perspectives on agriculture can be provided by the youth involvement.

According to Dwiartama et al, (2017), the involvement of young people will create an innovation through creativity. Urban youth created a movement in the agricultural sector through healthy food consumption and maintaining urban environmental conditions. The movement of youth in the urban agricultural sector is a form of crisis against the environment in urban areas that is able to encourage the socio-economic-health conditions of urban communities, maintain environmental conditions and maintain biodiversity in urban areas. Urban agriculture starts from the manufacture, processing and distribution of food and other products through intensive crop cultivation and livestock farming around the city [3].

The key concepts can be drawn from our 'new' youth studies are the notion of youth as an actor in social and economic reform, youth as identity, and youth as generation [17]. Actually, Indonesia is one of the countries in Asia that is potential to increase the portion of entrepreneurship related to agribusiness that is often referred to as agripreneurship. Through a movement, young people created an urban agricultural system that could promote sustainable urban life. The city of Bandung has a dependency on food production. Almost $97 \%$ of the food needs come from suburban areas such as Cianjur Regency, Majalengka Regency, Garut. Regency and Sumedang Regency [27]. Thus, youth is a key in creating an urban agricultural system through innovations created to address the problem of healthy and sustainable food needs.

The role of youth offers a variety of solutions to the problem of food and environmental crises through an

* Corresponding author: aakhmadzainal@gmail.com 
innovation it has developed, such as forming a movement from the practice of urban farming in groups. This movement initially criticized the availability of food that ignored the environmental and health conditions that consumed basic food for urban communities. It starts with paying attention to the food consumed by the urban community, so it is necessary to know the journey of food products to be served on a plate that will then be eaten. The movement from urban farming practices have a big goal to build public awareness of the need for healthy and food safe to consume. Through the role of youth who can provide benefits to urban communities about the world of agriculture managed with limited land, this is an important step to form an ecosystem from urban farming.

Many activities offered by the urban farming community so that people, especially those who live in cities, are involved in the practices they manage. It is hoped that the involvement of the wider community will be able to improve social relations between the community and society, thereby creating a system of exchange that will form a new hope for a sustainable urban community. On the other hand, some people are starting to realize that eating habits are not just for making the stomach full but they will consider the impact of consuming food itself. In the end, the community will determine the level of food safety for their own consumption.

Community become the young agripreneurship (agricultural entrepreneurs) based on the entrepreneurial interest. The phenomenon of community urban farming that consists of young agripreneurship and focuses on the agribusiness activities can be alternative solutions for young generation who has bad perception towards agriculture especially urban farming. The success of the program held by the community of urban farming practices is very interesting to study using the Logical Framework Analysis (LFA). The use of the Logical Framework Analysis is an approach that logically sees the success of the programs that have been carried out by the urban farming practice community. Therefore, it is necessary to know thoroughly about the activities carried out by the community in achieving its success.

Several previous studies have shown that there are several determining factors for farmers to do agribusiness, including personal characteristics [30,31,32] There are studies on entrepreneurship in organic agriculture [23], growth trends and increasing entrepreneurial activities in agriculture and related activities $[24,8]$. There are several studies that focus on farming management and supporting farming for entrepreneurship [19]. Concepts related to entrepreneurial orientation and market orientation for the success of an entrepreneur [13], youth perspective in farming [35].

In spite of copious literature on agricultural entrepreneurship, a major research gap could be noted. Discussions about entrepreneurial practices from urban farming are still rarely carried out even though they can contribute significantly to the activities that are successfully practiced. This study tries to fill in the entrepreneurial complexities of urban farming practices that are managed by a community where young people are the majority of members. This study tries to explore the activities of urban farming entrepreneurship through the Logical Framework Analysis which is used to see the success or inadequacy of a program from the results; impact (long term), outcomes (medium), and outputs (product); activities (activities) and input (finance, human, material resources).

The LFA scheme shows the activities and interventions occur and helps to identify the given inputs then produces outputs to achieve the goals, so that they can achieve the main target [10]. This research was conducted in Bandung City, West Java. The research objective is to analyze descriptively the interest and action of young agripreneurship on urban farming community and some factors influencing the interest and action of young agripreneurship on business systems in Bandung.

\section{Methods}

The research on the interest and action of young agripreneurship on the urban farming system with community as a superintendent was conducted especially in "1000kebun" community in Bandung City, West Java. This study uses descriptive qualitative methods in describing the detail of the phenomena that occur in field conditions [11]. This descriptive approach explains an object of research through the data that has been collected. It is relevant to describe ongoing events and related to the current conditions.

This research consists of primary data and secondary data. Primary data were obtained by researchers through in-depth interviews with managers in "1000kebun" community. Meanwhile, secondary data is in the form of data related to journals and social media that support research activities. The qualitative research method with a descriptive approach is in accordance with the focus of research that studies phenomena using the case study method and obtains sources of information through observations that describe management and development based on Logical Framework Analysis (LFA) which has been developed from an urban agricultural practice to form a community that involves youth. One of the factors of qualitative research is the need to explore, describe phenomena and develop theories [11].

\section{Result and Discussion}

\subsection{Community Profile}

1000kebun community was formed in 2015, which was originally an activity of youth in Arcamanik, who are interested in agriculture, especially in gardening and consuming food that does not use chemicals or organic substances. Starting from this, the community invited its neighbors to form another gardening community in the area where they lived. Through the 1000kebun forum, the active members are mostly young people. The members carried out many activities so that the name "1000kebun" has more appeal. The enthusiasm of the 
people of West Java is high for activities that originate from hobbies but then generate profits, now more people are interested in activities carried out by 1000kebun community and even some media such as online, newspapers, and television.

The activities of young people engaged in the urban agricultural sector through the use of limited land conditions, maximize the potential of waste that is considered to have no value, carrying out healthy and safe food cultivation known as 1000 kebun activities. Through the desire to improve the quality of human life and maintain healthy environmental conditions based on healthy food and create a community-based healthy lifestyle knowledge center. Apart from that, 1000kebun also facilitates access to healthy food, as well as its facilities and infrastructure.

\subsection{Urban farming Agripreneurship}

The concept of FAO regarding urban farming is not only to provide food in urban areas, but it is related to the quality of food that contains nutrients and the price offered, which is not just an economic measure, but a price for the health value of consumers and the environment. Urban people are willing to pay $22 \%$ more expensive than the market price to get the best food products such as organic products [29]. Therefore, many market demands are not fulfilled and many young people are interested in food and environmental health issues.

The emergence of the Movement in the agricultural sector which was created by many youths, got a good response in society. The motive of the urban farming group carried out by the community is to provide healthy and safe food for consumption. This is in accordance with Xie (2015) that the most important motive offered to consumers through organic product is that consumers get good benefits for health. If consumers expect good benefits for health, so the products presented must be protected from pesticide residues and be friendly to environmental conditions [33].

The practice managed by the community with efforts to improve nutrition, sustainable urban environmental management, and the large number of people who follow, ranging from men and women, productive age and unproductive age [9]. Despite the impressive urban development and the evolution of new sustainability movements, the demands for a healthy environment and lifestyles are what people have been take into account nowadays [4]. A community in Sydney, views that urban farming is part of a hobby, recreational activity, and an activity that increases income and enhances the beauty and ecological function of urban areas, in other words, increases the biodiversity in the city [20].

The activity carried out in the beginning was only to plant, now to help overcome stress on situations and create emotional bonds to get closer to the natural environment (Scott, 2012). The creation of a satisfaction atmosphere and relaxation can be achieved by immersing oneself in natural conditions. In agricultural countries, especially in developing countries, urban farming practices are carried out by communities with a lot of involvement from young people with their own goals and interests. Some communities practice urban farming to build closer relationships between members through agricultural practices. Therefore, this practice helps encourage each community to create new food networks outside the community in the course of this practice [12].

Creating a new food network through a self-created market mechanism attracts the attention of many people to participate directly in activities, so that it has benefits in creating a wider network. A survey conducted by Sharp et al (2002), reveals that urban farming is able to strengthen relationships between communities such as creating a sense of togetherness and a diverse culture between growers and farmers. This is what the community does in keeping its activities sustainable.

The urban farming practice carried out by the community become the young agripreneurship (agricultural entrepreneurs) based on the entrepreneurial interest managed by youth who create a new market strategy differently. Youth play an active role in the supervision, assistance and empowerment efforts of urban farming practices. The involvement of youth in the world of agriculture creates a regeneration that will produce a role in the social dynamics of the agrarian community that has been formed [2,5].

Agripreneurship is a sustainable employment strategy that will ensure self-reliance and economic selfsufficiency to the entrepreneur and also to the community of the entrepreneur [36]. Agribusiness includes the manufacturing and distribution of farm inputs, crop production activities, storage, processing, and distribution of farm products made from them [28]. The development of agricultural entrepreneurship refers to the promotion of entrepreneurial skills amongst common individuals and building the entrepreneurial approach in the field of agriculture [37].

Agripreneurship that is run by the urban farming community certainly requires input resources that can drive impact (long term), outcomes (medium) and outputs (products). Involving youth in community management is very influential in planning and involvement. The first step taken by the community of 1000kebun was to build a healthy lifestyle through the consumption of organic food which can improve human health and save the urban environment that has been increasingly polluted. The community of $1000 \mathrm{kebun}$ gets many connections from urban farming practices in creating sustainable city conditions, giving awareness to other individuals through their own means, starting from small things and starting from now on.

Urban farming that is developed by the community certainly has many innovations so that these activities become more attractive to urban communities. Innovations developed based on research and development related to the agricultural and nonagricultural sectors [18]The emergence of 1000kebun initially had a lot of information related to the agricultural sector, which was inaccurately in delivering the information and lack of human resources in developing a business from the agricultural system. However, it rise to an idea from the agricultural sector which was tried to be carried out in urban areas by 
attracting people, began to meet new humans to get information, and knowledge that form a framework for the urban farming system.

\subsection{Logical Framework Analysis}

The existence of urban farming community activities that are still running is an activity based on evaluations conducted by members of the community. The management of 1000kebun community is based on improving the quality of life through food and sustainability of the environmental conditions of the city in future. The form of management human resources carried out by 1000 kebun community towards their farmer members such as not using synthetic fertilizers and synthetic pesticides derived from chemicals which will add to the burden on food security conditions and environmental sustainability. These are the way to inform consumers regarding the conditions and quality to choose. Before being marketed, agricultural products obtained from farmers are confirmed to have their level using series of tests in accordance with SNI and Internasional Standards so that consumers get the right product.

The involvement of youth in urban farming practices from 1000kebun is not just planting and cultivating activities. It can create and manage marketing strategies that are different from existing markets. This is an innovation for the community in maximizing its existence. In addition to the marketing system that was developed, 1000kebun community create management that made easier for the manager to carry out their duties. The freedom to explore oneself through a community that is formed is a different way of creating an attractive management.

The cultivation technique used by $1000 \mathrm{kebun}$ is to attract many partners who want to join in the practice of urban farming. The management of 1000kebun in practice is to use goods that still have value and do not add to the burden on the environment, such as making vermicomposting by utilizing domestic waste to cultivate worms which are useful for health. In addition, the soil from worms is used as fertilizer for the plants they plant.

The long-term impact of the urban farming community is felt by community members, such as being able to take up a hobby, take advantage of free time, create jobs, exchange ideas through meeting new people, getting healthy from quality food, and getting other benefits. Meanwhile, people who participate in urban farming are separated from the community of 1000 kebun, getting access to healthy food and knowing about healthy lifestyles. Feeling the long-term impact requires adaptation to the habits of consumption patterns of the city community, 1000kebun community continues to develop programs to improve the quality of life and special food for urban communities.

Referring to Feenstra (2009) that direct marketing will be an indicator to revitalize and improve the relationship between farmers, non-farmers and consumers. The practice of urban agriculture contributes to addressing positive social welfare and enhancing community pride. 1000 kebun community created 1000 garden stalls for the surrounding community to easily gain access to healthy food. In addition, the provision of marketing services uses various kinds of social media such as Instagram and websites that make it easier for the wider community to access healthy food. So that in the medium term the community continues to be provided with good quality food. The marketing that 1000kebun done is not only selling from their agricultural products, there is sharing of experiences from the farmers directly related to the journey of food products to be served on plates which are often held by the 1000 plantation community in making the community more aware.

The output (products) of 1000kebun that are marketed at the 1000kebun stalls are not merely vegetables like other organic products imported from the surrounding community. The products that are sold are various kinds but are still related to products that do not damage nature and human health, in other words zero waste. The awareness of managers in maintaining the condition of municipal solid waste is increasing, causing the products they sell must be responsible for environmental conditions. In addition, the interest is the selection of food products that must meet the standards made by 1000 kebun based on national and international standards, so that the products sold have gone through various laboratory trials.

The advantage of 1000 kebun stall is that it presents a certificate next to the product or as a means of market education to consumers as well as material for promotion on social media. This can increase consumer confidence in buying products from the activities of 1000kebun. There are interesting things about the sale of the product, such as creating a story behind the product in the packaging; who grows, where it is planted, the impact of organic agriculture on environmental conditions in a sustainable manner, and there are benefits contained in the product or equalizing the vision and mission of 1000kebun stalls which increase the value of the products they sell.

Activities at 1000kebun, such as the healthy market, are routine activities every three months which carried out to promote products from community members. This activity also collaborates with farmers or other communities. Moreover, 1000kebun tour is also an event to trace the gardens of other members, and sharing knowledge to develop agricultural products. Furthermore, nebon seru and an online discussion are often held by 1000 kebun community. In addition, 1000 kebun community is active in collaborating with various groups and institutions related to the agricultural system.

The input that is managed by 1000 kebun community such as human resources that are capable of creating various kinds of other resources to support the activities of community. Creating a clear structure and division of tasks is an effective way of organizing the activity to be able to work productively. Learning from individuals involved in the community becomes a strategy in maximizing the potential and stimulating the emergence of various kinds of interesting innovations for the community in getting food products that are 
healthy and safe for consumption while maintaining a sustainable urban environmental condition.

Alsos et al (2011) argue that the ability and willingness of farmers to engage in entrepreneurial behavior is a useful tool in explaining the different patterns of success and failure in the sector. This in turn will prove to be useful because we ultimately seek to characterize entrepreneurship and business characteristics of young farmers in particular. Entrepreneurship, in simple terms, is a positive attitude towards risk [7]. Entrepreneurs innovate and create new business activities or modify existing activities to their advantage and to take the opportunities perceived in the market. Clark (2009), Boekhoelt (1998) and Pretty (1998) list some of the entrepreneurial characteristics associated with farmers: re-adopting agricultural production bases, adopting new market orientations, leveraging endogenous resources, adopting new forms of government, pursuing engagement and community support, and ultimately effective management of space and natural resources.

\section{Conclusion}

The activities and benefits provided by the community practice of $1000 \mathrm{kebun}$ greatly influence the food crisis in the urban area as well as generate various other benefits. Utilization of resources is a key to community management in creating a new market. To provide more lasting impact, various initial steps are needed, such as building a healthy lifestyle packaged by youth in the community to create a sustainable urban environmental solution.

\section{References}

1. Alsos, G.A, Carter, S, Ljunggren, E and Welter, F, (eds). 2011. The Handbook of Research on Entrepreneurship in Agriculture and Rural Development. Edward Elgar: Cheltenham

2. Archambault C, 2014. Young Perspectives On Pastoral Rangeland Privatization: Intimate ExcluSions At The Intersection Of Youth Identities. European Journal of Development Research 26:204-18.

3. Bailkey, Martin dan Nasr, Joe. 2000. From Brownfields to Greenfields: Producing Food in North American Cities. Community Food Security News, 6.

4. Bellows, A. C., State, T., Community, S., Trust, L., Smit, J., \& Urban, M. C. P. T. 2003. Health Benefits of Urban Agriculture. Agriculture, (January).

5. Berckmoes L, White B, 2014. Youth, Farming And Precarity In Rural Burundi. European Journal of Development Research 26:190-203.

6. Boekhoelt, P. 1998. South-East Brabant As A System Of Innovation. In Regional Innovation Systems, Bracyk, H, Cooke, $\mathrm{P}$ and Heidenreich, M (eds). pg 322-338. UCL Press: London.
7. Clark, J. 2009. Entrepreneurship And Diversification On English Farms: Identifying Business Enterprise Characteristics And Change Processes. Entrepreneurship and Regional Development. Vol 21, Number 2, pg 213-236

8. Chakraborty, D. (2014). Rural entrepreneurship development efforts-a study on entrepreneurural growth with special reference to Sonitpur District of Assam. Assam University, Diphu Campus.

9. Cohen, N., Reynolds, K., \& Sanghvi, R. 2012. Five borough farm: Seeding the future of urban agriculture in New York City. Design Trust for Public Space.

10. Coleman, G. 1987. Logical Framework Approach To The Monitoring And Evaluation Of AgriculturalDevelopment Projects. Project Appraisal 2(4): p 251-259.

11. Cresswell, J.W. 2014. Research Design: Qualitative, Quantitative, Mixed Methods (4th Edition). California: SAGE.

12. Dwiartama, A., Tresnadi, C., Furqon, A., \& Pratama, M. F. 2017. From Initiative to Movement: The Growth and Evolution of Local Food Networks in Bandung, Indonesia. Asian Journal of Social Science Studies, 2(4), 91.

13. Faria, J., \& Mixon, F. 2016. FarmerEntrepreneurs, Agricultural Innovation, And Explosive Research And Development Cycles. Administrative Sciences, 6(4), 13 https://doi.org/10.3390/admsci6040013.

14. G.W. Feenstra. 2009. Local Food Systems And Sustainable Communities. American Journal of Alternative Agriculture, Volume 12, Issue 01, pp. 28

15. Hamilton, W., Bosworth, G., \& Ruto, E. 2015. Entrepreneurial younger farmers and the "young farmerproblem" in England. Agriculture and Forestry, 61(4), 61-69.

16. Hubbard, M., Onumah, G. 2001. Improving urban food supply and distribution in developing countries: The role of city authorities. Habital International 25: 431-446.

17. Jones G, 2009. Youth. Cambridge: Polity Press.

18. Kem, S. 2017. Commercialisation of Smallholder Agriculture in Cambodia: Impact of The Cassava Boom on Rural Livehoods and Agrarian Change. Dissertatin. School of Agriculture and Food Sciences. The Univercity of Queensland.

19. Kahan, D. 2012. Entrepreneurship in Farming. Rome: Farm management extension guide Retrieved from http://www.fao.org/ uploads/media/5-EntrepreneurshipInternLores.pdf.

20. Knowd, I, D.Mason \& A. Docking. 2006. Urban Agriculture: The New Frontier", in City Structure 23, hlm.1-22

21. KRKP. 2015. Laporan Kajian Regenerasi Petani, Faktor faktor yang Mempengaruhi Minat Menjad 
Petani, $\quad$ pada Keluarga Petani Padi dan Hortikultura. Koalisi Rakyat untuk Kedaulatan Pangan bekerjasama dengan Australian Aid dan Oxfam.

22. Matuschke I. 2009. Rapid urbanization and food security: Using food density maps to identify future food security hotspots. Paper present to International Association of Agricultural Economist Conference-19th.

23. Munda, G. C., Das, A., \& Patel, D. P. 2014. Organic Farming In Hill Ecosystems-Prospects And Practices. Umiyam, Meghalaya. Retrieved from

http://www.kiran.nic.in/pdf/publications/Organic _Farming.pdf

24. Mujuru, J. T. R. 2014. Entrepreneurial Agriculture For Human Development: A Case Study Of Dotito Irrigation Scheme, Mt Darwin. International Journal of Humanities and Social Science, 4(4), 121131.

25. Pretty, J. 1998. The Living land. Earthscan: London

26. Proctor F, Lucchesi V. 2012. Smallscale Farming And Youth In An Era Of Rapid Change. London: IIED. http://pubs.iied.org

27. Puriandi, F. 2013. Proses Perencanaan Kegiatan Pertanian Kota yang Dilakukan oleh Komunitas Berkebun di Kota Bandung Sebagai Masukan Pengembangan Pertanian Kota di Kawasan Perkotaan. Journal of Regional and City Planning, 24(3), 227-240.

28. Rajesha, G., Talang, H., \& Kumar, R. 2016. Avenues for entrepreneurship development through agri-horti ecosystem for farmers and rural youth.

29. Sari, Yulia., elly rasmikayati., bobby .R. S., Tuti karyani., Sulistyo Dewi. 2020. Willingness To Pay Konsumen Beras Organik Dan Faktor-Faktor Yang Berkaitan Dengan Kesediaan Konsumen Untuk Membayar Lebih. Vol. 10 No. 1, Maret 2020; halaman 46-57. ISSN 2252-5491, E ISSN 2656-4599

30. Secundo G, Vecchio PD, Schiuma G, Passiante G. 2017. Activating Entrepreneurial Learning Processes for Transforming University Students Idea into Entrepreneurial Practices. International Journal of Entrepreneurial Behavior and Research. 23(3): 1-37. Doi: 10.1108/IJEBR-122015-0315.

31. Setiawan I, Sumardjo, Satria A, Tjitropranoto P. 2015a. Strategi Pengembangan Kemandirian Pelaku Muda Agribisnis "Brain Gain Actors" Di Jawa Barat. Jurnal Mimbar. 31(2): 409-418.

32. Setiawan I, Sumardjo, Satria A, Tjitropranoto P. 2015b. Study of Role of Agribusiness Young Actors on Optimalization of Private Agricultural Extension in West Java Province, Indonesia. International Journal of Humanities and Social Science. 5(9): 161-169.
33. Schobesberger, B. R., Darnhofer, I., Somsook, S., \& Vogl, C. R. 2007. Consumer Perceptions Of Organic Foods In Bangkok, Thailand. Elsevier. Food Policy 33 (2008), 112-121.

34. Sugiyono, S. 2012. Metode Penelitian Kuantitatif Kualitatif dan R\&D, Bandung: Alfabeta.

35. Sumberg, J., Yeboah, T., Flynn, J., \& Anyidoho, N. A. (2017). Young people's perspectives on farming in Ghana: a $Q$ study. Food security, 9(1), 151-161.

36. Uche, C., \& Familusi, L. 2018. The Adoption Of Agripreneurship As A Mitigating Measure To Unemployment In Nigeria: A Topical Review. Global Journal of Management and Business Research, 18(2), $25 \quad 31$ Retrieved from https://globaljournals. org/GJMBR_Volume18/3The Adoption-of Agripreneurship.pdf.

37. Uplaonkar, S. S., \& Biradar, S. S. 2015. Development Of Agriculture In India Through Agripreneurs. International Journal of Applied Research, 1(9), 1063-1066 Retrieved from www.allresearchjournal.com.

38. Wyn J, White R. 1997. Rethinking Youth. London: Sage Publications.

39. Xie, B., Wang, L., Yang, H., Wang, Y., \& Zhang, M. 2015. Consumer Perceptions And Attitudes Of Organic Food Products In Eastern China. British Food Journal, Vol. 117 Iss 3 pp. 11051121. 